\title{
ISIS Energy Sector As Material Capabilities In Establishing Islamic State Based On Robert W. Cox Approach
}

\section{Faris Febrianto}

Faris Febrianto

Affiliation : Universitas Pertamina,

City : Jakarta

Country : Indonesia

Email

Faris1702@gmail.com

\section{History \\ Submission : 16 June 2021 \\ Review : 20 September 2021 \\ Completed \\ Accepted : $\quad$ 20 December 2021 \\ Available $\quad$ : 30 December 2021 \\ Online}

\section{DOI :}

10.51413/jisea.Vol2.Iss2.2021.139-147

Copyright

This is an open access article distributed under the term of the creative commons attribution 4.0 international licence

\begin{abstract}
ISIS is a terrorist group that controls parts of Iraq and Syria which targets the energy sector in various attacks to control an energy source. Meanwhile, ISIS uses the energy sector to encourage its financial sector to be able to establish and maintain the Islamic State. In this article, the author uses a qualitative method that relies on internet-based research as a data collection technique and uses a Robert W. Cox approach for data analysis. This article aims to analyze the energy sector controlled by ISIS as material capabilities in realizing the Islamic State based on the approach of Robert W. Cox. The author finds that ISIS has control over oil refineries and natural gas fields in its territory so that it makes a large contribution to ISIS finances. The energy sector has also resulted in ISIS being able to establish the Islamic State and supply its military forces to defend it. Through the approach of Robert W. Cox, it can be concluded that the energy sector is a material capability owned by ISIS to build power and the Islamic State.
\end{abstract}

Key Words: ISIS, Energy Sector, Material Capabilities, Robert W Cox

\section{Cite this article :}

Febrianto, Faris. "Isis Energy Sector As Material Capabilities In Establishing Islamic State Based On Robert W. Cox Approach." Journal of International Studies on Energy $\begin{array}{llll}\text { Affairs 2, no. } 2 & \text { (2021): } 139-47 .\end{array}$ https://doi.org/10.51413/jisea.Vol2.Iss2.2021.139-147.
I TA Journal of Intenational Studies on Energy Affairs 


\section{INTRODUCTION}

Since the end of World War II, the issue of security has become an issue that is often discussed in International Relations and has increasingly gained its stage when entering the era of the Cold War. However, entering the end of the Cold War or to be precise in the 1980s, issues in International Relations became increasingly diverse due to the growing number of non-conventional issues. Environmental issues, public welfare, and health are examples of issues that have developed in International Relations since the end of the Cold War and have been discussed since then. This in the end changed the direction of discussion in International Relations which was initially dominated by security issues to become non-conventional issues. In addition, the security sector has also experienced developments in issues that can be seen from the events that occurred during the 1980 os to the 2000s. Terrorism is one of the non-conventional issues that is being discussed in International Relations to date, considering that this issue has an impact on other fields of public welfare.

Basically, the issue of terrorism itself has developed since 1980 which can be reflected in the Mujahideen group in Afghanistan in the events of the Soviet-Afghan War throughout the 1980s. In this case, the Mujahideen group in Afghanistan resulted in the formation of new militant groups that adopted an ideology similar to the Mujahideen groups in various countries. Referring to the definition of the US Department of State and Defense, terrorism is an act of violence that threatens noncombatant targets and is motivated by political motives from a group. In its development, terrorist groups are increasingly targeting non-combatant targets such as civilians who are very vulnerable to terrorist attacks. The 9/11 attacks in 2001 were one of the terrorist attacks carried out by the Al-Qaeda group and resulted in the death toll of up to 2977 people died and 25,00o people were injured. These events indicate that terrorist attacks can cause enormous casualties in a country and can be carried out by only one group. Therefore, terrorism is one of the non-conventional issues that becomes a further concern to be discussed in the realm of International Relations considering the impact it has had is very large.

The Islamic State of Iraq and Syria (ISIS) is a terrorist group originating from the Middle East that has occupation in parts of Iraq and Syria. ISIS is an affiliate of AlQaeda in 2004 which was originally a branch of Al-Qaeda in Iraq and began with the establishment of Jamaat al-Tawhid wa-l-Jihad (JTWJ) in 1999 by Abu Mus"ab Al-Zarqawi. ISIS has the goal of establishing a caliphate or state based on Islamic sharia laws. However, ISIS has committed various violations in realizing this and has caused many fatalities for ISIS' actions using violence. In addition, ISIS declared the establishment of the Islamic State on June 29, 2014 with Abu Bakr al- 
Baghdadi claiming to be the caliph of the country. In this case, ISIS declares the establishment of the Islamic State over the areas it has controlled and is part of the ISIS caliphate. Through the Islamic State, ISIS has also stated that it has the highest political, military, and religious authority over the region and invites all Muslims in the world to support the Islamic State (Rizal, 2017).

Meanwhile, energy has become one of ISIS' targets in several of its actions such as attacking energy infrastructure, smuggling oil, and controlling oil refineries in Iraq and Syria. This can be seen from the actions of ISIS which smuggled oil from Turkey and controlled several oil refineries such as al-Tanak, al-Omar, and al-Taqba since 2015. Through smuggling and control over oil refineries, ISIS can produce its own oil by total production reaches 16,000 to 20,000 barrels. Basically, ISIS oil production will be used to finance the construction of its caliphate, namely the Islamic State (Tichý, 2019). Therefore, this study will discuss how ISIS uses petroleum as a support for the establishment of Islamic States through the approach of Robert W. Cox. The research question posed by the author in this study is based on the introduction described earlier, namely "How does ISIS use the energy sector as material capabilities based on Robert W. Cox's approach to establishing an Islamic state?".

The first article is an article written by Giacomo Luciani in 2011 with the title "Armed conflicts and security of oil and gas supplies". The article written by Luciani discusses the impact of civil war, war between countries, and terrorism on global oil and gas supplies. In this case, Luciani uses qualitative research methods to analyze data obtained from institutions and MNCs such as the IEA and BP. Luciani focuses on systematically analyzing the impact of armed conflict in several oil and gas producing countries. The article written by Luciani emphasizes that the impact of armed conflict does not have a serious impact on global oil and gas supplies. However, Luciani revealed that armed conflict actually has an impact on a country's economy. Luciani's research is the basis for the author in understanding how the energy sector is used by terrorist groups economically.

Furthermore, there is a journal article entitled "ISIS Political Economy: Financing a Terror State" and written by Dimitrios Stergiou in 2016. The article written by Stergiou discusses how ISIS manages its economy in order to achieve its goal of building an Islamic state or caliphate. In this study, Stergiou used an analytical qualitative approach and obtained data from interviews with residents. Stergiou aims to investigate ISIS funding sources and the process of managing these funds in the financial aspect of ISIS. Stergiou's research results reveal that ISIS obtains these funds from terrorist attacks and other criminal acts. In addition, research conducted by Stergiou also found that ISIS has its own system for managing its 
finances. In this case, the author confirms that there is no similarity between the research discussion and the discussion in Stergiou's research.

Third, there is a journal article written by Jamie Hansen-Lewis and Jacob N. Shapiro in 2015 entitled "Understanding the Daesh Economy". Hansen-Lewis and Shapiro in their journal articles discuss the analysis of ISIS economic opportunities in the long term with economic principles. In this case, both authors used qualitative research methods in their research and obtained data from official documents, interviews, and journal articles. Hansen-Lewis and Shapiro aim to show that economic principles apply equally under ISIS leadership. The results of Hansen-Lewis and Shapiro's research illustrate that ISIS does not have good economic opportunities in the long term. Even though it has applied economic principles, ISIS still has an area of power that is very vulnerable to conflict so that it is not economically stable. Through this journal article, the author gets an overview of the sources of ISIS income and emphasizes that there is no similarity in the discussion with this study.

The next literature review is a journal article entitled "The Unanticipated Threat of ISIS: Rise, Growth, and Stability" written by Wes Cooper. In his journal article, Wes Cooper examines how ISIS uses the financial aspect to support its organization and explains the development of ISIS. Journal articles written by Wes Cooper use qualitative research methods and rely on official documents and articles as data sources. Wes Cooper focuses on describing the development of ISIS by leveraging community and financial support. The result of Wes Cooper's research is that ISIS has succeeded in growing due to the disenfranchisement of rights in Iraq and Syria which has led to public support for ISIS. In addition, ISIS also began to finance the activities of its organization by obtaining funds from several ways such as selling petroleum, selling stolen goods, and extortion. Wes Cooper's research provides an understanding for the author of how ISIS can support its organization through the sale of petroleum.

The last literature review is an article written by George Kiourktsoglou and Alec Coutroubis in 2015 entitled "Isis export gateway to global crude oil markets". George Kiourktsoglou and Alec Coutroubis discuss the energy trade established by ISIS in their article. The two authors of the article used an explanatory qualitative method and used interviews, official documents, and journal articles as data sources. In their article, George Kiourktsoglou and Alec Coutroubis aim to identify the illicit trade carried out by ISIS. The results of the study show that ISIS has a strong petroleum supply chain to the global petroleum market. ISIS uses sea routes such as the Ceyhan Port in Turkey to carry out illicit trade with the global petroleum market. This research provides an overview for the author of ISIS's energy business 
in making a profit and makes it clear that there is no similarity in the discussion with this study.

Antonio Gramsci was one of the philosophers from Italy during World War II whose thoughts on hegemony inspired Robert W. Cox. Through Gramsci's thinking, Robert W. Cox sees how a country seeks to protect its hegemony in the international order. By combining the thoughts of Classical Marxism, Robert W. Cox finally found a new approach to hegemony in a modern way. Robert W. Cox thinks that the world today no longer uses hard power as the main power owned by a country. At the time of World War II, the international order was marked by hegemonic countries that prioritized hard power as power. According to Robert W. Cox, at this time a country tends to use other ways to maintain its hegemony.

In this case, Robert W. Cox considered that a country seeks to maintain its hegemony in the international order through power that can be formed from several factors. The factors to form power for a country are having a strong ideology, having qualified material capabilities, and having an institution. These three factors can shape the power of a country and produce hegemony in the international order. In addition, these three factors must also be interconnected with each other in order to form the hegemony needed by a country. Therefore, Robert W. Cox formed a framework to describe these three factors in his new approach to modern hegemony.

\section{METHODS}

In this study, the authors limit the discussion of the research so that the research conducted does not have a broad and undirected discussion. The author decides to limit the discussion of the research to the material capabilities aspect of ISIS in Robert W. Cox's approach. As stated in the research question not to look at other aspects of Robert W. Cox's approach. The author will also only focus on discussing the energy sector as an aspect of ISIS' material capabilities through the approach of Robert W. Cox. The objectives to be achieved in this study are to identify the energy sector used by ISIS to support its activities and objectives based on material capabilities in the Robert W. Cox approach. Meanwhile, there are research benefits to be obtained in this study, namely to find out how ISIS can use the energy sector to support its activities and goals based on material capabilities in Robert W. Cox's approach.

Through the approach of Robert W. Cox, ISIS has had both factors to form power in the international order as a step to create an Islamic state. First, ISIS has a thought that originated from the Islamic extremist movement, namely the Muslim Brotherhood in the 1920 s with its anti-Western. In addition, ISIS also has a similar 
understanding to Marxism, namely dividing the two major groups in the world into fidels and infidels. Fidels are a group of Muslims who believe and pledge allegiance to ISIS while infidels are a group of people who do not believe or disbelieve. These two groups are the basis for ISIS to justify each of its actions and claim that ISIS has the right to destroy infidels (Tiara and Handayani, 2016). Although very radical, these thoughts are an ideology built by ISIS in order to realize its goals.

Second, material capabilities are the next supporting factor for ISIS to form power in realizing its ideals, namely establishing a caliphate. In this case, ISIS builds strength through various means such as imposing taxes (jizya) in its territory and selling oil to the government. Petroleum is one of the material capabilities possessed by ISIS by controlling several oil refineries within its territory. One example is the government of Bashar Al-Assad which is involved in buying petroleum products from ISIS (Speckhard and Yayla, 2016). The last factor is having an institution that can connect and run the two previous factors. Even though they already have mass media, namely the Dabiq propaganda magazine, until now ISIS has not had a clear institution in forming power.

\section{DISCUSSION AND FINDINGS}

Since 2013, ISIS has been increasingly aggressive in expanding its territory in Iraq and Syria by controlling most of the area by its fighters. In 2014, ISIS declared the establishment of an Islamic state or caliphate which was in line with the group's goals. With a fairly large territory, ISIS must have strong financial sources to finance all the activities of its Islamic state. According to the US Department of Treasury, ISIS earned at least $\$ 20$ million USD in ransom from extortion. In addition, ISIS is also predicted to earn up to $\$ 1$ million USD per day from the sale of oil, which is ISIS' biggest income. The large amount of ISIS income has resulted in the group becoming 'independent' and able to develop an Islamic state (Cooper, n.d.). As explained in the approach of Robert W. Cox, the amount of ISIS income from the energy sector can be a material capability it has.

Since ISIS established an Islamic state, ISIS has gained control over several oil fields or refineries that previously belonged to the Syrian and Iraqi governments. In this case, ISIS has control over eight petroleum refineries namely al-Tanak, al-Omar, alTabqa, al-Kharata, al-Shoula, Deiro, al-Taim, and al-Rashid. Al-Tanak is the largest petroleum refinery controlled by ISIS and is capable of producing around 11,00o12,000 barrels of oil per day. Through its control of petroleum refineries, ISIS is able to produce 30,000 to 40,000 barrels of oil per day at a price of around $\$ 20-$ $\$ 40$ USD per barrel. In addition, ISIS also smuggles petroleum into neighboring countries in various ways to get more profit. Some of these ways can be done by ISIS 
by using boats, pipes, walking, and riding horses or donkeys. To smuggle petroleum, ISIS tends to use jerry cans as storage containers so that it is easier for smugglers to carry (Solomon, Kwong, and Bernard, 2015).

Energy has become an important component in various terrorist attacks carried out by ISIS which are ISIS' interests in the energy sector. ISIS has three main focuses in its energy interests, namely increasing control of oil refineries in Iraq and Syria, increasing oil and gas production, and seizing new oil refineries. The three main focuses also have the goal of securing ISIS finances and weakening the economies of western countries. It can be concluded that natural resources are the main financial key for ISIS to maintain its power and Islamic state. In fact, the Shura or the organization's board has considered oil and natural gas as the main instruments in maintaining and expanding the Islamic state. Therefore, the energy sector is still directly controlled by the highest command even though al-Baghdadi has divided authority to his subordinates (Tichý, 2019).

The main goal of ISIS in regulating its energy sector is to maximize the full potential of energy reserves within its territory. To take advantage of the existing potential, ISIS seeks to build its own energy industry so that it gains stable profits in the long term. This vision emerged when ISIS began to occupy large areas in Iraq and Syria which had an impact on access to oil refineries and natural gas fields. As a result, ISIS controls oil and natural gas production by $60 \%$ in Syria and $10 \%$ in Iraq since 2014. In addition to oil, natural gas is also ISIS' main focus in the energy sector, which has a similar goal, namely to increase ISIS income. The terrorist group has control of several natural gas fields in Syria and Iraq which have reserves totaling $1,360 \mathrm{~m} 3$ cubic feet of natural gas per day. Through control over natural gas fields, ISIS was able to increase revenues from natural gas sales by up to $\$ 489-\$ 979$ million USD per year (Tichý, 2019).

From the energy sector, ISIS is able to create its own market to sell its oil and natural gas production in order to develop its Islamic state de jure. Turkey, Jordan, Iran, Iraqi Kurdistan, and even the Syrian government are foreign customers of ISIS' oil being smuggled across the border. One of ISIS' foreign customers, Iraq Kurdistan, paid half the international price for oil and $\$ 1500$ USD for its tankers. In this case, ISIS benefits from three ways, which include selling the oil it produces, assigning costs to intermediaries, and imposing taxes at every checkpoint controlled by ISIS. In addition, ISIS has also created its own domestic market in order to have a reliable source of finance. Through the domestic market, ISIS has another goal to create dependence on the people in its territory by providing cheap oil prices. In addition, ISIS also uses income from the energy sector to build ISIS military forces (Stergiou, 2016). 
Through the approach of Robert W. Cox, ISIS has a very large material capacity from its income in the energy sector so that it can be used to create an Islamic state. This can also be reflected in the consideration of the organization's board which states that oil and natural gas are the main instruments to maintain an Islamic state. Not only that, ISIS is able to create its own market, both domestic and global, which is another source of income. With revenues of up to $\$ 1$ million USD per day, ISIS has the material capabilities to support the costs of building an Islamic state. In addition, ISIS sees how energy is the main key to building its military forces and seeks to utilize its energy reserves for its defense sector. The energy sector has made a very important contribution for ISIS to build its power and establish an Islamic state.

\section{CONCLUSIONS}

Terrorism is an unconventional issue in international relations that has developed since the 200os and has varied until now. ISIS is a terrorist group that uses various means to achieve the goal of realizing an Islamic state. The energy sector is one of ISIS' targets in its terror attacks which aim to gain control over a natural gas field or an oil refinery. Through the approach of Robert W. Cox, it can be said that the energy sector has become a material capability that can boost ISIS finances so that they are able to build an Islamic state. As has been explained, ISIS also uses the energy sector to provide a fleet of military troops so that they are able to build strength to defend the Islamic state. Therefore, ISIS is a terrorist group that has great material capabilities from the results of its oil and natural gas industry.

\section{REFERENCES}

Cooper, W. The Unanticipated Threat of ISIS: Rise, Growth, and Stability. Towson University Journal of International Affairs, 47-58.

Hansen-Lewis, J., \& Shapiro, J. N. (2015). Understanding the Daesh economy. Perspectives on Terrorism, 9(4), 142-155.

Luciani, G. (2011). Armed conflicts and security of oil and gas supplies. CEPS Working Documents. Retrieved from https://www.jstor.org/stable/pdf/26297422.pdf

Rijal, N. K. (2017). Eksistensi dan Perkembangan ISIS: Dari Irak Hingga Indonesia. Jurnal Ilmiah Hubungan Internasional, 13(1), 45-60. Retrieved from

https://journal.unpar.ac.id/index.php/JurnalIlmiahHubunganInternasion a/article/view/2670

Shelton, H. (1998). Joint tactics, techniques and procedures for antiterrorism. Joint Pub, 3-07. Retrieved from https://fas.org/irp/doddir/dod/jp3 07 2.pdf 
Solomon, E., Kwong, R., Bernard, S. (2015). Inside Isis Inc: The journey of a barrel of oil. Financial Times. Retrieved from https://ig.ft.com/sites/2015/isisoil/

Speckhard, A., \& Yayla, A. S. (2016). ISIS revenues include sales of oil to the alAssad regime. ICSVE Brief Reports.

Stergiou, D. (2016). ISIS political economy: financing a terror state. Journal of money laundering control. Retrieved from https://www.emerald.com/insight/content/doi/10.1108/JMLC-06-2015o021/full/html

Tiara, N., \& Handayani, W. P. (2016). MENGENAL ISIS LEBIH DEKAT: MENYOAL IDEOLOGI GERAKAN ISIS: MENYOAL IDEOLOGI GERAKAN ISIS.Jisiera: The Journal of Islamic Studies and International Relations, 1(2), 157-172. $\quad$ Retrieved from http://journal.insiera.org/index.php/jisiera/article/view/13/17

Tichý, L. (2019). Energy infrastructure as a target of terrorist attacks from the Islamic state in Iraq and Syria. International Journal of Critical Infrastructure Protection, 25, 1-13. Retrieved from https://www.sciencedirect.com/science/article/abs/pii/S18745482173020 93

Tichý, L. (2019). The Islamic State oil and gas strategy in North Africa. Energy Strategy Reviews, 24, 254-260. Retrieved from https://www.sciencedirect.com/science/article/pii/S2211467X19300288 